\title{
The Grammar of Case
}

Towards a Localistic Theory

JOHN M. ANDERSON

Mr Anderson explores, within the framework of transformational-generative grammar, the 'localized hypothesis' which asserts that all the roles for nouns involve basically the notions of location and direction.

£5.40 net

\section{CAMBRIDGE STUDIES IN LINGUISTICS 5}

\section{Linguistic Evolution}

\section{With Special Reference to English}

\section{L. SAMUELS}

The first book to present a comprehensive treatment of the reasons for linguistic change. Professor Samuels avoids alignment with any particular school of linguistics; his purpose is to show that the conflicting dogmas of different schools can be reconciled, and that future progress in the subject is likely to come from intensified study of the few languages with a long recorded history.

\section{Pidginization and Creolization of Languages}

Proceedings of a Conference held at the University of the West Indies, Mona, Jamaica, April 1968

\section{Edited by DELL HYMES}

The Introduction by David DeCamp gives a guide to current theories on pidgins and creoles, their origin, diffusion and, in some cases, decline. Professor Hymes provides a preface and introduction to each of the five parts of the book.

$\therefore \ldots$ an essential textbook in the theory and practice of sociolinguistics ... this collected volume on the study of pidgins and creoles will be of fundamental interest to all those engaged in the study of language in general and in the interrelated problems of languages as a social phenomenon.'

The Times Higher Education Supplement

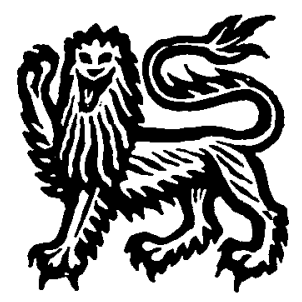

CAMBRIDGE UNIVERSITY PRESS 


\section{Linguistics in Language Teaching}

D. A. WILKINS

The idea that linguistics is a subject of particular interest and value to foreign language teachers is one that has become increasingly accepted in recent years. This book relates current linguistic thought to the practical problems of language teaching, including English as a foreign language. The author has adopted a deliberately practical approach: he has not attempted to promote a single theoretical view or to provide a complete survey of theoretical linguistics, but rather to discover 'through discussion of a wide range of topics how far decisions in language teaching can be, and in some instances have been, informed by a knowledge of linguistics'. 


\title{
Journal of the International Phonetic Association
}

\author{
(formerly Le Maître Phonétique)
}

\section{NOTES FOR CONTRIBUTORS}

Policy.-The Journal of the International Phonetic Association, formerly entitled Le Maître Phonétique, is concerned with all aspects of phonetics and phonology, on which subjects it publishes articles, specimens, correspondence, and reviews. The official language is English, though contributions in other languages of wide currency will be published as the Editor thinks fit.

Style.-Contributions should be submitted in typewritten form, in double spacing with wide margins, on one side of the sheet only, on quarto or A4 paper. Phonetic transcriptions should make use of the symbols and conventions of the Association's alphabet. If phonetic or other symbols have to be added to the manuscript by hand, they should where appropriate be identified in the margin by their grid co-ordinates shown in the journal's Reference Table of Phonetic Symbols (available from the Editor on request). Phonemic symbols should be enclosed in slants, but allophonic or generalphonetic symbols in square brackets, e.g. /tel/, [thet], [m]. Cited forms should be italicized, without quotation marks; translational 'meanings' and quotations should be placed within single quotation marks. Technical terms and other words to which it is desired to give particular emphasis may be printed in SMALL CAPITALS, but NOT in italics. Footnotes should be avoided as far as possible; where essential they should be numbered consecutively throughout the manuscript. References are to be made IN THE TEXT by giving in parentheses the name of the author and the year of publication, and where relevant the page or pages referred to: e.g. '... (Jones, 1963 : 452-3) . . . All works so referred to should be listed, with full bibliographical details and in alphabetical order, at the end of the article. Names of books should be italicized, but titles of articles placed between single quotation marks.

Proofs and offprints.-Two copies of proofs will be sent to the author (or his nominee), who will be expected to correct them and return them to the Editor, by airmail where appropriate, within ten days of receipt. Upon publication, fifty copies of a contribution will be supplied to the author free of charge; further offprints may be purchased at cost. 


\section{Publications of the}

\section{International Phonetic Association}

The Principles of the International Phonetic Association (1949). A description of the International Phonetic Alphabet and the manner of using it, illustrated by texts in 51 languages. 40p (to members 25p).

Chart of the International Phonetic Alphabet (1951). 2p (to members 1p).

The History and Meaning of the Term " Phoneme" (1957, reprinted with corrections 1967). By D. Jones. 20p (to members 14p).

Miscellanea Phonetica II (1954). Articles by D. Jones, A. Martinet, E. V. Pike and E. Fischer-Jørgensen. 25p (to members 18p).

Miscellanea Phonetica III (1958). Articles by P. Ladefoged, M. H. Draper and D. Whitteredge, M. R. Wise, E. Matteson and K. L. Pike, and G. Hammarström. 30p (to members 20p).

Differences between Spoken and Written Language (1948). By D. JoNEs. $5 p$ (to members $3 p$ ).

La Phonétique et ses Applications (1929). By Paul Passy. 5p (to members 3p).

Notes on the Dialect of Nidderdale (Yorkshire) (1922). By M. L. AnNakin. 5p (to members 3p).

The Russian i-i Phoneme (1947). By S. C. Boyanus. 3p (to members 2p).

Back issues of Le Maître Phonétique may be obtained from the Secretary, International Phonetic Association, University College, London WC1E 6BT at the following price :

1941-70: $£ 1 \cdot 00$ per year (to members 70p).

Numbers published before 1941 may be obtained from Swets \& Zeitlinger N.V., Reprint Department, Keizersgracht 471 \& 487, Amsterdam, Holland, to whom enquiries should be sent. 